weight; and that, so far from desiring to choose the man most qualified for the office, their choice has already been determined mainly by private and personal considerations. I find, further, that great ignorance prevails in the minds of many vestrymen as to the proper qualifications and duties of a sanitary officer: special scientific attainments and sanitary knowledge they regard with marked disfavour, and consider that his sphere lies in the detection of bad odours and the use of chloride of lime and whitewash. They know nothing about, and many of them are incapable of appreciating, the subtle influences which induce disease, or the nature of those means which should be employed to obviate its occurrence. Lastly, the fact has been impressed on my mind that but few men could hold the appointment of officer of health for St. Marylebone without being subjected to indignities to which no gentleman ought to be called upon to submit, and which few men would be willing to encounter. The late Dr. Thomson, I am grieved to learn, was at times sorely tried by conduct which only an individual of a very forbearing disposition, and nne actuated by a high sense of duty, could have tolerated ; while for myself, I have been informed that even less consideration would be shown in the event of my election. One influential vestryman remarked, "Well, if your friend is a gentleman, and succeed in getting the appointment, I pity him the fate that awaits him." Another well.known vestryman observed to myself, "If you get in you will be insulted, bullied, and in fact, Dr. Hassall, they will worry you to death." While a third-one of the few who will undoubtedly give his vote for the candidate best fitted for the office, - when the case was put to him in a personal form, exclaimed, "I would sooner break stones than be placed in such a position !"

Under these circumstances, I desire it should be known that I am no longer a candidate for the appointment; and I make this announcement with a sense of great relief. I may state further that I was induced to become a candidate not merely from the considerations to which I have adverted in the opening paragraph of this letter, but also in consequence of the wishes and opinions of a very large number of my professional brethren resident in the parish. To these gentlemen, as well as numerous friends who have thus honoured me with their good opinion and confidence, and who iuterested themselves in the matter, I beg to tender my warmest thanks.

With one other remark I close this letter, in the hope that I may not have occasion further to trespass on your valuable space. Mr. Nicholay and others have, for their own purposes, studiously misrepresented the nature of my qualifications and pursuits. They have referred to me simply as an analyst and microscopist, ignoring the fact of my having held im. portant sanitary appointments, of my being senior physician to a metropolitan hospital, and daily engaged in practice as a physician.

Thanking you, Sir, for the part you have taken in this im. portant public and professional question,

I remain your obedient servant, Arthor Hill Hassall, M.D. Lond.

Wimpole-street, Sept. 8th, 1864 .

\section{THE PROVIDENT FUND AND THE JOURNAL OF THE BRITISH MEDICAL ASSOCIATION.}

\section{To the Editor of The LanceT.}

SIR,-I have addressed the enclosed letter to the many gentlemen with whom I was in communication last year on the subject of the Provident Fund. I send a copy to you (and also to your contemporaries), that it may, if you see fit, receive further publicity in your columne.

I am, Sir, faithfully yours,

Strond, Sept. 4th, 1864.

R. B. CARTER, F.R.C.S.

Dear SIr,- - The time has at length arrived at which $I$ can make to you a definite report on the subject of the proposed Medical Provident Fund.

In the summer of 1863 , I had already obtained the necessary statistical information, and hoped to see the Fund speedily established, when I was informed that Dr. Ricbardson, at the Annual Meeting of the British Medical Association, was about to move for a committee to inquire in to the whole subject. In consequence I attended the meeting at Bristol, and my name was added to the list of the proposed committee, which was directed to report to the next meeting of the Association, at Cambridge.
Feeling sure that affiliation to the British Medical Association would be highly beneficial to the Provident Fund, and feeling also that the report of the committee would deservedly carry far more weight than the labours of any individual, I willingly ceased from independent action in the matter, and gave all the assistance in my power to the framing of the com. mittee's report. With that report I am well satisfied in all respects but one, with regard to which I appended my individual protest against the views of my colleagues. The report and protest have been published in the medical journals, and have doubtless already fallen under your notice.

The report was adopted by the Association, and Dr. Richardson was appointed chairman by the vote of the annual meeting. At an early meeting of the Committee of Council the Council Directorate will be chosen, and the various branches will be called upon to elect their directors. When this is done the Board will be fully constituted, and will be in a position to admit members, with a view to the commencement of sick payments in July, 1865 .

The tirst duty of the Board, however, will be to decide points left open by the report, and consequently left open by the vote of the annual meeting. First among these questions will be the subject of my protest-namely: Shall the Provident Fund be open to all members of the profession, or shall it be limited to members of the British Medical Association.

The majority of the committee, who were and are in favour of the limitation, regarded the matter from an Association point of view. I mean that they are old members of the Asso. ciation, that they have laboured for it in various ways for many years, that they are proud of its progress, and hopeful of its future. They think that it will become an important political engine for the elevation of the profession, and a power that the Cirumlocution Office will not be able to ignore. They think that the Provident Fund will strengthen the Association, and they therefore welcome it for the sake of the Association, rather than for the sake of the men who will chiefly need its belp. I, on the other hand, and those who think with me, while we should rejoice to see the most sanguine anticipations of the friends of the Association realized, yet feel that there are many practitioners whom sickness would render destitute. There are men of small capital striving to establish themselves, there are qualifitd assistants who aid in maintaining widowed mothers or younger brothers and sisters, and there are esta. blished practitioners who, from local circumstances, are almost precluded from earning incomes sufficient for their needs. I conceive that it would be an act of cruelty to call upon such men to subscribe an annual guinea to the British Medical Association, before admitting them to become members of the Provident Fund.

But as many of my colleagues in the committee differ from me, and think that such a call ought to be made, I am tempted to ask what return the guinea will bring. The political and other anticipated benefits are not yet realized. The meetings and speeches and dinners are necessarily limited to men in comparatively easy circumstances, and the less affluent mem. bers receive for their subscription only a copy of that Journal upon which about ten elevenths of the income of the Association are expended, and which rnust always, from the operation of commercial laws, be inferior to its contemporaries that are maintained by private enterprise. The present deplorable position of the Journal, and its recent advocacy of superficial attainments and of trading greed, although they cast some re. flected discredit upon the Association, are yet mere accidents, due to causes that are temporary, or, at least, that admit of being removed. Still the fact that such accidents are possible, that they have nccurred, and may recur, increases the hardship of asking any man to pay for a publication that may offend his taste and judgment in every number, and that he cannot discontinue without forfeiting his right to obtain provision during sickness.

I apprehend, however, that the organization of the Association, apart from the Journal, would be of great value to the Provident Fund, and I think that the subscribers to the Fund should be prepared to pay for the use of that organization. I would suggest, therefore, that every subscriber to the Provident Fund should contribute two shillings a year to the executive expenses of the Association generally - that being rather more than the proportion of the ordinary subscription that is not absorbed by the Journal, - and that the Board of Directors should be applied to as soon as formed to admit subscribers upon such a basis.

That such a proposal may be acceded to, those who are in farour of it must bestir themselves. They must endeavour to procure the election, by the branches in their respective neigh- 
bourhoods, of directors who will support it at the Board ; and they must seek to obtain the names of practitioners who wish for admission on the terms proposed. I should like the directors to consider the question of limitation under the pressure of 200 or more applications from gentlemen who are not members of the Association, and who are prepared, in the event of being refused, to establish a separate fund of their own. From all such I shall be most happy to receive communications.

I have observed in the journals some letters criticizing the Report of the Committee, and suggesting various improvements. To all these letters there is one reply. The suggestions of the writers are usually practicable-at an increased rate of subscription. There is no reason why the Provident Fund should not extend its operations in many ways; but it is best to begin cautiously, and to wait for experience before attempting too much.

I am, dear Sir, yours very faithfully. Robert Brudenell Carter, F.R.C.S.

Stroud, Gloucestershire, Sept. 1864.

\section{POOR.LAW MEDICAL REFORM. To the Editor of THE LANCET.}

SIR,-I shall feel obliged by your giving insertion to the following correspondence, which will inform the Poor-law medical officers that there is a prospect of some relief being yet afforded them; whether that relief will be of a substantial character or not time will disclose. A liberal measure on the part of the Poor-law Board may tend to allay much of the present dissatisfaction which prevails amongst their medical officers; the reverse will most certainly drive us to lay our grievances before the House of Commons next Session, and woe betide those members at the general election who turn a deaf ear to our complaints. I have votes in two counties and a borough, and it is my intention to give my support to those six members only who will promise their aid to an equitable adjustment of the system of Poor-law medical relief. If all the medical practitioners would do the same the grievances of the Poor-law medical officers would quickly vanish.

I remain, Sir, your obedient servant,

12, Royal-terrace, Weymouth, Sept. 1864.

Richard GRIFFin.

12, Royal-terrace, Weymouth, Aug. 22nd, 1864.

Mr LoRds And Genrremen, - On the 11th of last March the Select Committee on Poor Relief recommended "that in future cod-liver oil, quinine, and other expensive medicines shall be provided at the expense of the Guardians, subject to the orders and regulations of the Poor-law Board." As some months have elapsed since the recommendation was made, I take the liberty to ask the favour of your informing me if it is your intention to issue any order on the subject, or whether you propose to bring the recommendation of the Committee before Parliament next Session. I make this inquiry on public grounds, as many Poor-law medical officers have written to me respecting the recommendation.

I have the honour to be, my Lords and Gentlemen, Your obedient servant, Richard GRIFFIN.

The Poor-law Board. Poor-law Board, Whitehall, Sept. 2nd, 1864.

SIR, - I am directed by the Poor-law Board to acknowledge the receipt of your letter of the 22nd ult., and to inform you that the subject to which you refer has been under their consideration; but that they have not yet come to a decision as to the measures which it may be desirable to recommend the guardians of the different unions to take with reference to the resolution of the Select Committee on Poor Relief as regards the supply of expensive medicines.

The question, however, will receive the attention of the Board forth with.

I am, Sir, your obedient servant,

Richard Griffin, Esq., 12, Royal-terrace, Weymouth.

H. Flemirg, Secretary.

\section{THE BURIAL.GROUND AT SCUTARI.}

To the Editor of THe LANCET.

SIR, - With reference to an article that appeared in your jonrnal of the 20th of August on the above subject, I addressed a letter to Earl Russell, and stated that $I$ had ventured to do 80 as the father of a beloved and lamented son who was interred at Scutari. I think it will be satisfactory to the feelings of many, whose deceased relatives are buried there, to read the following prompt and decisive reply to my letter, for which I feel very grateful to his Lordship.

I am, Sir, your obedient servant,

Christ's Hospital, Hertford, Sept. 5th, $1864 . \quad$ GEORGE LDDLOW.

Foreign Office, Sept. 3rd, 1864.

Sir,-I am directed by Earl Russell to acquaint you, in reply to your letter of the 27 th ultimo, that measures will be taken for the protection of the British Cemetery at Scutari.

I am, Sir, your most obedient humble servant, George Iudlow, Esq.

Christ's Hospital, Hertford.

E. HAMMOND.

\section{alledical 影etos.}

ApothrCariks' HaLL. - The following gentlemen passed their examination in the Science and Practice of Medicine, and received certificates to practise, on the lst inst. :-

Bramhall, Sykes, Clifton.

Grellet, Charles John, Lloyd-street, Lloyd-square.

Hickenbotham, James, Birmingham.

Huckenbotham, James, Birmingham.

Hughes, David, Charing-cross Hospital.

Powne, Benjamin Lamb, Billingborough, Lin
Thursfield, 'Thomas Greville, Broseley, Salop.

Vise, William Hoster, Spalding, Lincolnshire.

The following gentlemen also on the same day passed their first examination :-

Piteher, Arthur Henry, St. Thomas's Hospital.

Rogers, Henry Cripps, St. Bartholomew's Hospital.

University of Edinburgh : Professorship of SURGERY. - The Court of Curators of the University of Edinburgh on Wednesday last elected Mr. Spence to the Professorship of Surgery, vacant by the decease of the late Professor Miller. The contest lay, as was foreseen, between Mr. Spence and Mr. Lister, of Glasgow. Opinions were greatly divided, and the decision appears to have been arrived at not without diffculty. Mr. Spence was elected by a majority of one.

M. Nelaton has just received a very handsome gold medal from the Italians resident in Peru as a token of their gratitude for his attendance at La Spezzia.

Medrcal Charities.-The late William Salt, Esq., banker, of Lombard-street and Park-square, Regent's-park, has bequearhed to the Stafford Infirmary and the Northern Dispensary, Euston-square, the sum of $£ 200$ each, free of legacy duty.

Faliaciods Statistics.-The following extraordinary announcement appears in one of the leading journals :- "From an official document just issued, it appears that on the last return there were as many as $1,142,624$ insane paupers."

Typhus Fever at Mecca. - The pilgrims travelling to Mecca to visit the tomb of the prophet have introduced typhus fever into the city, which has suffered most aeverely from its ravages.

Profissor Lawson, Lecturer on Physiology at the Queen's College, Birmingham, and in the deparcment of Science and Art, South Kersington, having resigned the appointment, has been elected Joint Lecturer on Physiology and Histology at St. Mary's Hospital Medical School, London, with especial charge of the department of Histology.

Quenn's College, BirminghaM.-Dr. Foster has been elected Professor of Anatomy in this College on the recom. mendation of the medical faculty. They have recommended that Mr. Lloyd should succeed Dr. Foster in the Chair of Descriptive Anatomy, which the Council will no doubt endorse. Dr. Willoughby Wade has resigned his appointment of the Chair of Practical Medicine, on the ground of increasing private professional duties.

Vaccination and Sypricis.-It is but too true that syphilis has been engrafted upon infants with the cow-pox virus; but a great reaction is at hand, for $M$. Lukomski cures lnes venerea by vaccination. We gather this from an article in the Revue MLÉdicale of Paris (A pril 30, 1864, ) and from a circular addressed to the medical profession by $M$. Lukomski. It would appear that, as far back as 1858, the author induced several hospital surgeons of Paris to try his laethod: the report of the proceedings was highly unfavourable. Cndismayed, however, 